\title{
Indicators of the Internal Environment of Gasconne Calves during Rearing
}

\author{
Aleš Pavlík ${ }^{1}$, Radka Zahrádková ${ }^{2}$, Daniel Bureš ${ }^{2}$, Pavel Jelínek $^{1}, Z_{\text {deněk Havlíček }}^{1}$ \\ ${ }^{1}$ Department of Animal Morphology, Physiology and Genetics, Mendel University of Agriculture and Forestry \\ in Brno \\ ${ }^{2}$ Department of Cattle Breeding, Institute for Animal Science, Prague Uhříněves \\ Received May 5, 2008 \\ Accepted October 1, 2008
}

\begin{abstract}
Selected indicators of the internal environment were determined in 11 bulls and 11 heifers of the Gasconne breed. Blood was sampled and the live weight was recorded on a regular basis at ages of 64, 99, 127, 155, 190, 216 and 253 days. Plasma concentrations of total proteins, urea, glucose, total cholesterol, triacylglycerols, total bilirubin, activity of alkaline phosphatase, alanine- and aspartate aminotransferase, concentrations of triiodothyronine, thyroxine, calcium, phosphorus, magnesium, potassium, sodium, iron, zinc and copper were assessed. The effects of $\operatorname{sex}(p<0.01)$ on changes in the concentration of total proteins, urea and total cholesterol $(p<0.05)$ were found. Enhanced growth intensity had a positive effect on the concentration of total cholesterol $(\mathrm{r}=0.52$; $p<0.05)$ but a negative correlation was detected between the growth intensity and activity of ALT $(\mathrm{r}=-0.50 ; p<0.05)$, AST $(\mathrm{r}=-0.46 ; p<0.05)$, and magnesium $(\mathrm{r}=-0.35 ; p<0.05)$. The age of the animals affected the concentration of plasma triodothyronine $(\mathrm{r}=-0.45 ; p<0.05)$, ALP $(\mathrm{r}=$ $-0.64 ; p<0.05)$, urea $(\mathrm{r}=-0.66 ; p<0.05)$ and iron $(\mathrm{r}=-0.34 ; p<0.05)$. The indicators of internal environment determined in this study were within the physiological range and therefore helped to specify the health and nutritional status of animals reared in extensive suckling cows systems.
\end{abstract}

Beef calves, rearing, internal environment, blood plasma

Permanent grassland is an important landscape-forming element which fulfils both production role as well as non-market benefits. We can expect that the extending of permanent grassland areas will continue due to the high share of cultivated agricultural land in the Czech Republic as compared with the EU-15. Cattle play a decisive role in exploitation of permanent grasslands in the Czech Republic; particularly cows reared in the system of suckling cows. This is the only category of cattle whose number of herds is permanently increasing. However, productive role of the system of suckling cows is important in the EU-15, too. Approximately two thirds of the beef produced in the EU come from beef breeds and their cross-breeds and about one third comes from dairy cow herds. Even though the number of suckling cows per one unit of area in the Czech Republic is substantially lower than in the EU-15 in terms of the production of top-quality beef, it is an important category of cattle.

Changes in indicators of the internal environment of farm animals reflect the actual metabolic processes. The respective indicators of the metabolic and mineral blood profile can be used for objective and reliable evaluations of the nutritional status of cattle (Ndlovu et al. 2007). However, the correlation between nutritional and production factors, the variability in the levels of metabolites and energy balance in the individual cattle categories have not yet been clarified (Cavestany et al. 2005). Differences in the production of the individual animal-based products could be associated with the different concentrations of hormones and metabolites in animal blood (Ban-Tokuda et al. 2007). In order to maximise production in cattle rearing based on the genetic potential and system of organisation according to Pereira et al. (2008), it is important to improve knowledge of the physiology and behaviour of cattle of the respective breeds. The results of earlier studies (Sasaki et al. 2002) show that information on

Address for correspondence:

Ing. Aleš Pavlík, Ph.D.

Department of Animal Morphology

Physiology and Genetics,

Mendel University, Zemědělská 1, 61300 Brno

Czech Republic

Phone: +420545133148

E-mail:pavlik@mendelu.cz

http://www.vfu.cz/acta-vet/actavet.ht 
the concentration of blood metabolites in cattle can be used to assess genetic ability when breeding the population for a specific purpose. The objective of the present study was to record the changes of selected indicators of the internal environment of the Gasconne beef breed calves during pasture rearing. Such information may be valuable for evaluation of the functional and health status of beef cattle breeds reared in the suckling cow system; on the basis of their growth rate, feed consumption and marketability it may also contribute to a better orientation of breeders in terms of nutrition, age and respective category.

\section{Materials and Methods}

The experiment was conducted at the special-purpose farm of the Institute for Animal Science in Prague Uhříněves with 11 male calves and 11 heifer calves of the Gasconne beef breed reared in the suckling cow system. The calves were selected by the date of birth, with the smallest possible age differences. The first blood samples were taken at the average age of $64 \pm 18$ days.

All the calves were weaned at the average age of 250 days. Male calves were transferred to the experimental stable where they were fattened. Heifers were separated from the stock herd until the end of the mating period in the following year. The feed ration (Table 1) consisted primarily of the mother's milk and pasture herbage with addition of hay, with the exception of the period between age 99 and 127 days when the carrying capacity of the pasture herbage was insufficient and the herd had to be fed additionally with a feed ration based mostly on alfalfa hay. After weaning both the bulls in the experimental stable and the heifers were fed a mixed feed ration. At each blood sampling the pasture herbage was sampled too and analysed for standardised nutrients (Table 1). At the age of 64, 99, 127, 155, 190, 216 and 253 days the body weight gain of the animals was recorded and blood was taken from the subcaudal vein using the Hemos sampling system (Gama Group, CR). The blood samples were treated with heparin and centrifuged at $1200 \mathrm{~g}$ for $20 \mathrm{~min}$. The blood plasma was kept at $-20^{\circ} \mathrm{C}$ until analysis.

Table 1. Content of standardised nutrients in feed during the monitored period

\begin{tabular}{|c|c|c|c|c|c|c|c|c|c|}
\hline $\begin{array}{c}\text { Animal } \\
\text { age (days) }\end{array}$ & Feed & Fibre \% & Ash \% & СР \% & $\begin{array}{c}\text { NEG } \\
\mathrm{MJ} \cdot \mathrm{kg}^{-1} \mathrm{DM}\end{array}$ & $\begin{array}{c}\text { RDP } \\
\mathrm{g} \cdot \mathrm{kg}^{-1} \mathrm{DM}\end{array}$ & $\mathrm{pH}$ & $\begin{array}{l}\text { Acetic } \\
\text { acid \% }\end{array}$ & $\begin{array}{l}\text { Lactic } \\
\text { acid } \%\end{array}$ \\
\hline 64 & Pasture & 30.2 & 6.80 & 8.43 & 3.85 & 56.2 & & & \\
\hline 99 & Pasture & 25.7 & 12.80 & 10.02 & 4.28 & 60.8 & & & \\
\hline 127 & TMR & 6.92 & 2.43 & 4.75 & 2.26 & 25.5 & 3.9 & 0.88 & 2.68 \\
\hline 155 & Pasture & 21.3 & 9.40 & 9.17 & 4.55 & 57.8 & & & \\
\hline 190 & Pasture & 15.8 & 14.20 & 17.89 & 4.51 & 101.6 & & & \\
\hline \multirow[t]{2}{*}{216} & Pasture & 21.5 & 8.50 & 17.86 & 4.74 & 101.4 & & & \\
\hline & Hay & 26.7 & 6.90 & 9.67 & 4.53 & 59.4 & & & \\
\hline
\end{tabular}

NEG: net energy for growth

CP: crude protein

RDP: ruminally degraded protein

TMR: total mix ration

The following indicators of the metabolic profile were determined in the plasma: total proteins (TP), urea, glucose (Glu), total cholesterol (Chol), triacylglycerols (TAG), total billirubin (Bil), alkaline phosphatase (ALP), alanine aminotransferase (ALT), aspartate aminotransferase (AST), thyroxine (T4), triiodothyronine (T3). The following indicators of the mineral profile were determined: calcium (Ca), inorganic phosphorus $(\mathrm{P})$, magnesium $(\mathrm{Mg})$, potassium $(\mathrm{K})$, sodium $(\mathrm{Na})$, copper $(\mathrm{Cu})$, zinc $(\mathrm{Zn})$ and iron $(\mathrm{Fe})$. The indicators of the metabolic and mineral profile were analysed using the automatic analyser XT20i (Fischer Thermo Scientific, Finland), T3 and T4 were determined on the automatic analyser Immulite (DPC, USA) using standard commercial kits (Biovendor-Laboratorní medicína, CR). Growth intensity during rearing was calculated on the basis of average body weight gains in time intervals between the individual samplings.

Statistical evaluations of the data were performed using the STATISTICA 7.0 programme. Two-way ANOVA with repeated measures for the sex factor as an independent variable and age factor as a dependent variable was used. ANOVA was followed by the post-hoc Fisher's LSD test for pairwise comparisons, when appropriate. Correlations among the age of the animals, body weight gains and individual indicators of the internal environment were evaluated by means of the correlation coefficient at the level of probability $(p<0.05)$. 


\section{Results}

Based on two-way ANOVA with repeated measures for the sex factor it was discovered that in the studied period the body weight gains (Table 2) of bulls were higher than of heifers $(\mathrm{F}(1,20)=9.6328=0.003)$. At the end of the experimental period, i.e. after weaning, the body weight gains of both groups decreased significantly $(\mathrm{F}(6,120)=14.210<0.001)$, as did the average gains. The average gains of bulls from day 216 to day 253 of age showed negative values.

Table 2. Average daily body weight gains of the animals in the experimental period $\left(\mathrm{g} \cdot \mathrm{day}{ }^{-1}\right)$

\begin{tabular}{|c|c|c|c|c|c|c|c|c|c|}
\hline & \multicolumn{4}{|c|}{ Bulls } & & \multicolumn{3}{|c|}{ Heifers } & \\
\hline Sampling & Period (days) & mean & & SEM & $p$ & mean & & SEM & $p$ \\
\hline 1. & $64-99$ & 604 & \pm & 75.5 & $\mathrm{a}$ & 444 & \pm & 89.9 & $\mathrm{~b}$ \\
\hline 2. & $99-127$ & 1058 & \pm & 58.3 & $\mathrm{a}$ & 772 & \pm & 70.1 & $\mathrm{~b}$ \\
\hline 3. & $127-155$ & 1136 & \pm & 52.7 & $\mathrm{~A}$ & 720 & \pm & 44.2 & B \\
\hline 4. & $155-190$ & 1248 & \pm & 59.9 & $\mathrm{~A}$ & 963 & \pm & 66.3 & B \\
\hline 5. & $190-216$ & 1385 & \pm & 112.4 & & 1257 & \pm & 54.3 & \\
\hline 6. & $216-253$ & -122 & \pm & 91.5 & & 54 & \pm & 72.2 & \\
\hline
\end{tabular}

$\mathrm{a}, \mathrm{b}: p<0.05 ; \mathrm{A}, \mathrm{B}: p<0.01$

Table 3 and 4 give the average indicators of the internal environment of bulls and heifers during the studied period. Concentrations of blood plasma total protein of both the bulls and heifers did not change considerably in this period. A slight increase was detected in both groups from day 253 of age. By means of the two-way ANOVA with repeated measures we found differences $(\mathrm{F}(1,20)=2.6328, p=0.042)$ for the factor sex. From the beginning of the experiment until day 127 of age the blood plasma urea concentrations in bulls increased. In heifers no marked changes were detected. At the age of 155 days the urea decreased in both groups. Up to the end of the experimental period the urea concentration increased $(\mathrm{F}(6,120)$ $=4.210, p=0.015)$. An increase $(p<0.05)$ in the urea concentration was detected on day 190 of age. Using the two-way ANOVA with repeated measures for the factor sex $(\mathrm{F}(1,20)$ $=10.6328, p<0.001)$ and Fisher's LSD post-hoc test higher $(p<0.01)$ urea concentrations were recorded in heifers on the $64^{\text {th }}$ and $155^{\text {th }}$ days of age and higher $(p<0.05)$ on the $190^{\text {th }}$ day than in bulls. On the contrary at 253 days of age the concentration was higher $(p<$ $0.01)$ in the bulls. The concentration of plasma glucose changed during the experimental period $(\mathrm{F}(6,120)=4.487, p=0.013)$. The levels of plasma glucose were the highest in the period from the beginning of the experiment until days 64 to 99 of age and were followed by a decrease $(p<0.05)$ in the average values at the age of 127 days. Until the end of the experiment the changes in the concentration were variable in both categories and had no unambiguous trend. Two-way ANOVA with repeated measures for the factor time revealed changes in the concentration of total cholesterol during the experimental period $(\mathrm{F}(6,120)$ $=13.487, p<0.001)$. From the beginning of the experiment the content of blood plasma total cholesterol of heifers gradually increased up to day 155 of age; in the group of bulls it increased until 190 days of age. Up to the $216^{\text {th }}$ day of age the average values slightly decreased in both groups. The concentration of plasma cholesterol significantly decreased on the $253^{\text {rd }}$ day of age. During the experiment we did not see an unambiguous tendency in the changes in triacylglycerol concentrations in either group. Lower average values were found at the end of the experimental period. Differences in the TAG concentrations between the categories were not significant. The content of blood plasma billirubin did not change markedly during the experimental period either; the average values changed $(p<0.05)$ on the $253^{\text {rd }}$ day of age in both categories. Considerably higher catalytic concentrations 


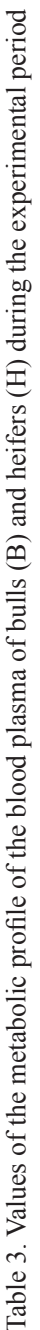

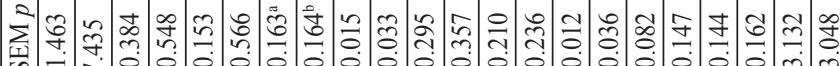

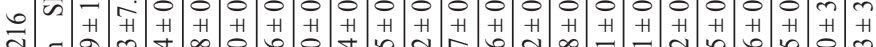

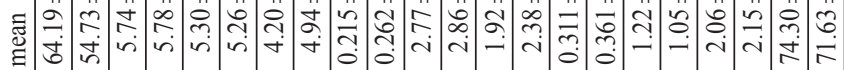

$\approx$

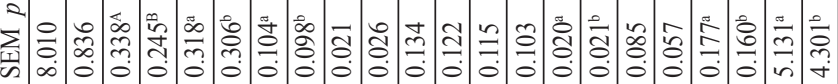

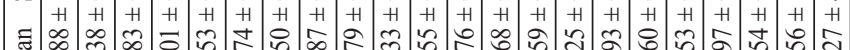

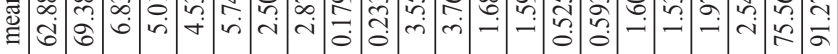

ஓ

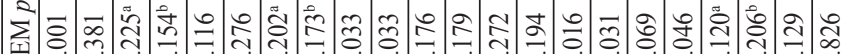

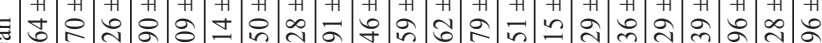
घ)

厺

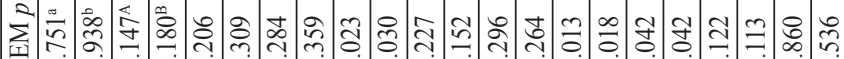

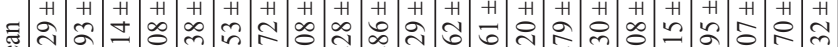
छ̋

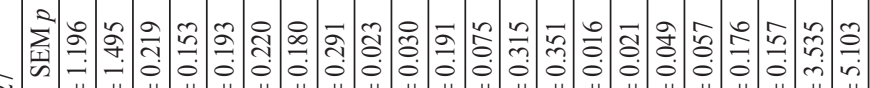

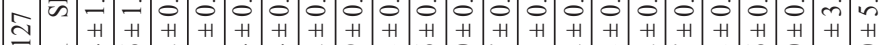

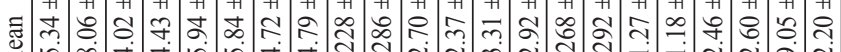

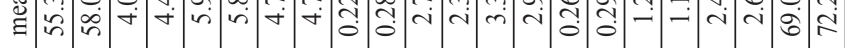

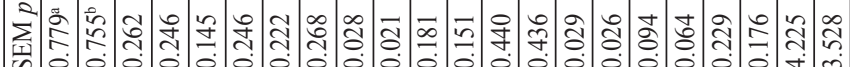

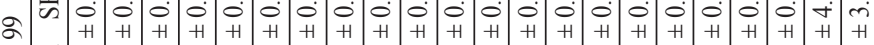

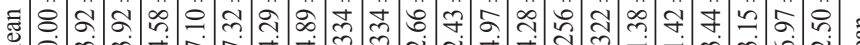

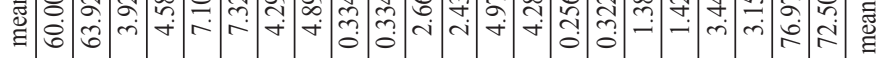

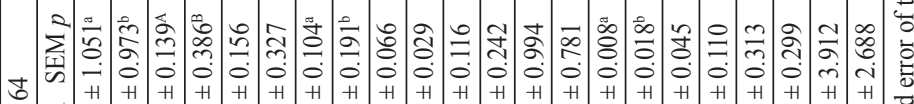

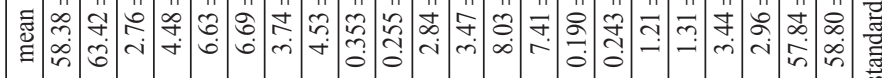

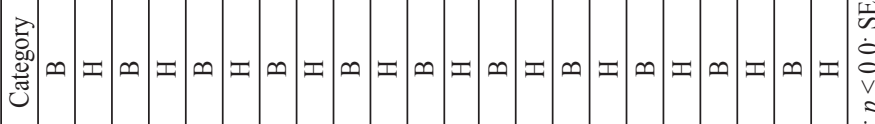

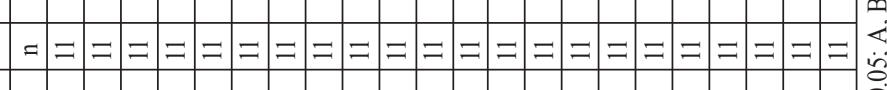

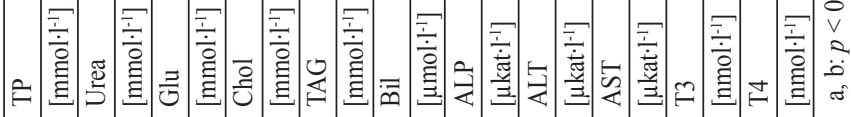




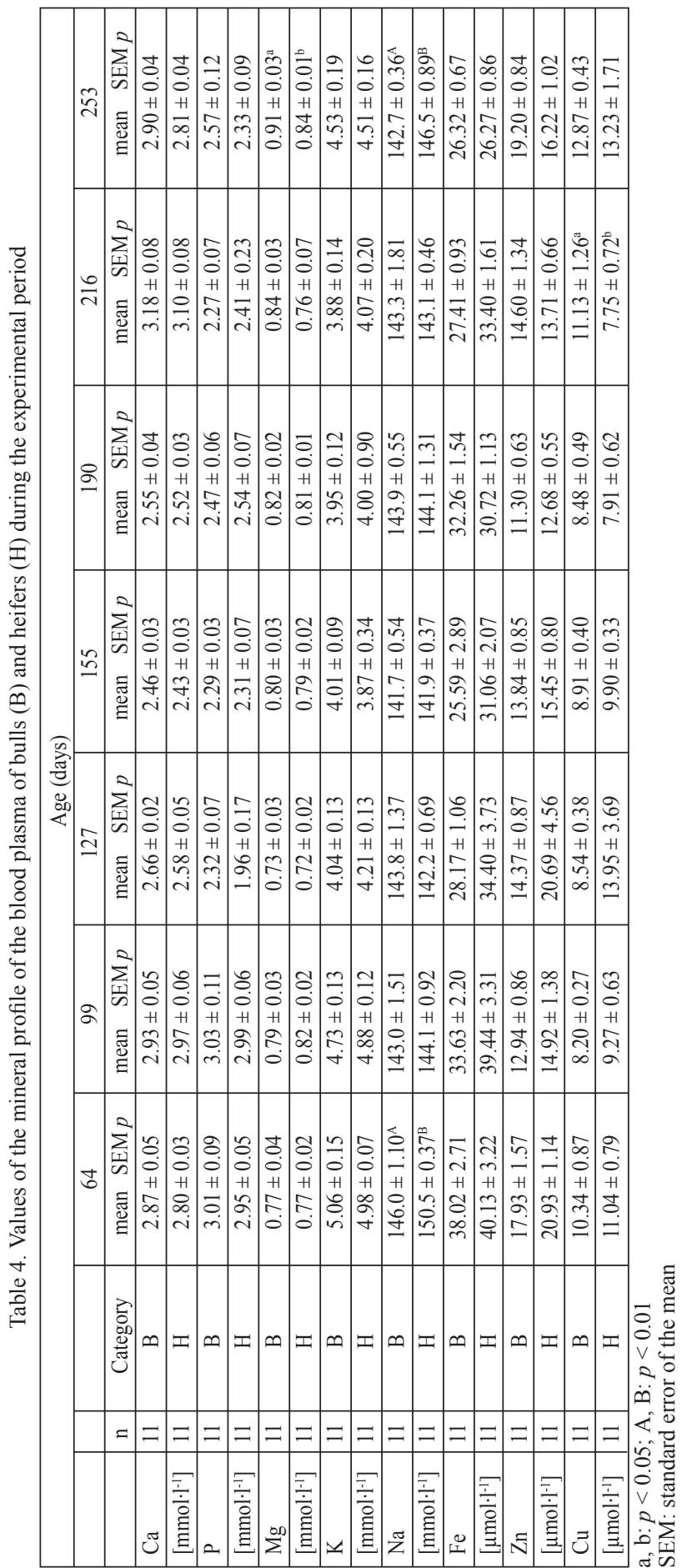

of alkaline phosphatase were found at the beginning of the experimental period ( $\mathrm{F}$ $(6,120)=9.102, p=0.002)$ at the age of 64 days $(p<0.01)$. With advancing age of the animals the activity of this enzyme decreased in both categories. A decrease $(p<$ 0.05 ) was also detected at the age of 127 days. Changes in the catalytic activity of alanine aminotransferase (ALT) showed an opposite tendency in both categories of animals. With only slight fluctuations its concentration increased from day 64 to day 253 of age. Using the twoway ANOVA with repeated measures for the factor time this increase was reported as significant $(\mathrm{F}(6,120)=6.947$, $p=0.004)$. The activity increased both in bulls and heifers on day $99(p<0.05)$ and day $253(p<0.01)$ of age. Sex was seen to affect the ALT activity $(F(1,20)=2.632$, $p=0.025)$. No differences between the categories in the catalytic concentrations of AST were monitored. The average values increased $(p<0.05)$ from the age of 253 days in both categories (F $(6,120)=3.712, p=$ $0.011)$. The concentration of triiodothyronine decreased in both categories from the beginning of the experimental period with slight fluctuations until the end of the experiment at the age of 253 days ( $F$ $(6,120)=5.489, p=0.005)$. A decrease $(p<0.05)$ was discovered in both categories on days 127 and 155 and in heifers on day 216 of age. Based on the results of the two-way ANOVA with 
repeated measures for the factor sex $(\mathrm{F}(1,20)=1.928, p=0.031)$ sex affected the level of triiodothyronine. The changes in thyroxine concentrations during the experiment were the opposite. At the age of 99 days the concentration of thyroxine was seen to increase significantly in both categories of animals. Also in this case we saw the effect of sex on the concentration of this indicator $(\mathrm{F}(1,20)=2.015, p=0.029)$.

During the experiment the concentrations of blood plasma calcium fluctuated slightly and higher average levels were detected in both groups at the beginning and at the end of the experimental period. The plasma calcium increased significantly at the age of 216 days in both bulls and heifers. The two-way ANOVA with repeated measures for the factor time discovered a significant effect of the age $(\mathrm{F}(6,120)=2.210, p=0.027)$ on plasmatic phosphorus. At the age of 127 days the concentration of phosphorus decreased in both groups $(p<0.05)$ and until the end of the experiment the average values did not markedly change. A slight fluctuation in the average concentrations of magnesium during the experiment was detected in both groups of animals. At the end of the experiment, from the age of 216 to 253 days, its concentration increased in both categories. However, the effect of age was not significant. A significant effect of $\operatorname{sex}(\mathrm{F}(1,20)=1.365, p=0.037)$ on the level of plasma magnesium was found.

Changes in the concentration of plasma potassium of the bulls and heifers were characterised by its higher concentration at the beginning of the experiment. From the $127^{\text {th }}$ day the average levels decreased $(p<0.05)$ and the concentration slightly fluctuated in both categories followed by an increase $(p<0.05)$ from the $253^{\text {rd }}$ day of age until the end of the experiment. The differences between the bulls and heifers were not significant. The trend in the changes was similar for concentrations of blood plasma sodium. The effect of sex on the sodium level was significant $(\mathrm{F}(1,20)=8.6328, p=0.004)$. During the entire experimental period the average concentrations of plasma copper and zinc fluctuated. Individual values in both groups of animals showed considerable variability. With fluctuations from day 190 to 216 of age the concentration of plasma iron decreased from the beginning of the experimental period until the end of the experiment $(\mathrm{F}(6,120)=12.574, p<0.001)$. In the group of bulls at the age of 99, 127 and 190 days the decrease was significant $(p<0.01, p<$ 0.05 and $p<0.05$, respectively). A decrease was detected in the group of heifers at the age of 127 and 253 days ( $p<0.05$ and $p<0.01$, respectively).

Based on the results of this study it is obvious that a higher growth rate expressed by the body weight gain for the given period had a positive effect on the concentration of total cholesterol $(\mathrm{r}=0.52 ; p<0.05)$ and, by contrast, that there is a negative relation between the growth intensity and activity of ALT $(\mathrm{r}=-0.50 ; p<0.05)$, AST $(\mathrm{r}=-0.46 ; p<0.05)$, and magnesium $(\mathrm{r}=-0.35 ; p<0.05)$. Changes in the indicators of the internal environment were also affected by the age of the animals, e.g. the correlation coefficient for the concentration of plasma triiodothyronine reached a value of $\mathrm{r}=-0.45(p<0.05)$, for the catalytic activity of ALP $r=-0.64(p<0.05)$, urea $r=-0.66(p<0.05)$ and iron $r=-0.34(p<0.05)$.

\section{Discussion}

From our results it is apparent that sex affects the concentrations of some indicators of the metabolic blood profile. A significantly higher level of total proteins was found in the plasma of heifers than in the bulls during the first months of the experiment, i.e. at the average age from 64 to 155 days. Likewise the average concentrations of urea were higher in the group of heifers. The level was significantly higher at the beginning and in the middle of the experimental period. Otto et al. (2000) also discovered higher urea concentrations in heifers $\left(4.51 \mathrm{mmol} \cdot l^{-1}\right)$ than in bulls which corresponds to the average values detected in our experiment. According to these authors the concentration of glucose was higher in the blood of bulls, but this was not confirmed in our experiment and neither 
in the study of Ban-Tokuda et al. (2007). Godden et al. (2001) much like Grünwaldt et al. (2005) refer to the many factors affecting the concentrations of plasma urea such as, apart from pathological manifestations, particularly the amount of received feed proteins and their rumen degradation, dietetic composition of the received amino acids and the ability of rumen degradation of sugar. Due to the identical composition of the feed ration (pasture herbage) of both groups of animals and differences in their growth rate, the effect of the sex on the level of urea could be based on the higher capacity of transformation of nitrogenous substances into amino acids and proteins resulting in faster growth of the organism, as Otto et al. (2000) reported.

During the entire period of our experiment the average concentrations of total cholesterol were higher in the group of heifers than in the group of bulls, and in most cases this difference was significant. Ban-Tokuda et al. (2007) arrived at similar results and in contrast to our results they pointed out that the concentrations of plasma TAG were higher in heifers than in bulls. These authors, much like Bonnet et al. $(2000,2004)$ attributed this trend to the different fat metabolism in association with hormonal and enzymatic activity, distribution of body fat and development of fat cells. Earlier studies connected the increased level of cholesterol with a better energy balance (Cavestany et al. 2005), and with the uptake of fat (Wittwer et al. 1987). In contrast, in other studies it was assumed that it was the result of a lack of energy (Bruss 1997). The effect of sex on the plasma concentration of the other indicators of the metabolic and mineral profile was discovered in sporadic cases or not at all and the changes in their concentrations may be connected with changes in the nutrient composition of the consumed feed. In our studies the concentrations of major elements were within the physiological range which was stated e.g. by Whitaker et al. (1999) and Grünwaldt et al. (2005). The amount of plasma copper in the respective categories of animals was also within the physiological range (Suttle 1993). Higher concentrations of iron than those presented by Kaneko et al. (1997) were recorded in bulls at the beginning of the experimental period and in heifers during the entire period.

Changes in some indicators of the internal environment were also affected by the age of the animals. In both groups the urea concentration increased during the experimental period. This trend corresponds with the findings of Otto et al. (2000) who detected higher urea levels in the blood of older animals. The age of the animals also affected the catalytic concentration of ALP which gradually decreased during the experimental period. Such tendency is apparent also in other animal species and is the result of rapid growth of young animals when ALP, appearing during mineralization of bone tissue, is released from the growing bones into the blood (Kaneko et al. 1997; Knowles et al. 2000). Otto et al. (2000) arrived at similar results and reported the correlation of age and ALP -0.649.

At the end of the experimental period the body weight gains considerably decreased in both groups; it was probably caused by weaning together with changes of life conditions, separation from the mother, change in the composition of the feed ration and lower feed intake connected with it. Together with lower growth intensity we recorded changes in the concentrations of some blood metabolites. The blood plasma concentration of urea, total billirubin and activity of ALT and AST significantly increased in both bulls and heifers. On the basis of these changes we can assume an increased functional loading of the liver in connection with a negative energy and nitrogen balance (Parra et al. 1999; Cavestany et al. 2005). A positive relation was reported between the body weight gains and concentration of plasma cholesterol. When the body weight gains at the end of the experimental period decreased the concentration of total cholesterol decreased significantly. Ban-Tokuda et al. (2007) reported that this decrease is probably caused by a reduction in the intake of feed.

The specified indicators of blood plasma extend and complement the characteristics of the internal environment in Gasconne calves during rearing; a topic which had not 
so far been explored in this breed in the Czech Republic. The average values of the indicators of the metabolic and mineral profile of the entire group of animals were within the physiological range for the given category. In this study, we observed the effect of the factors of sex, age and growth intensity on the changes in selected indicators of the internal environment. This information will help to improve the accuracy of assessment of the health and nutritional status of animals reared in extensive conditions of the suckling cow system.

\section{Indikátory vnitřního prostředí gaskoňských telat v průběhu růstu}

U 11 býků a 11 jalovic masného plemene Gasconne byly v průběhu odchovu stanoveny vybrané indikátory vnitřního prostředí. Odběr krve a zjištování živé hmotnosti byly provedeny v pravidelných intervalech ve věku 64, 99, 127, 155, 190, 216, 253 dnů. V krevní plazmě byly stanoveny koncentrace celkových bílkovin, močoviny, glukózy, celkového cholesterolu, triacylglycerolu, celkového bilirubinu, alkalické fosfatázy, alanina aspartát aminotransferázy, trijodtyroninu, tyroxinu, vápníku, fosforu, hořčíku, draslíku, sodíku, železa, mědi a zinku. Byl zjištěn vliv pohlaví $(p<0,01)$ na změny koncentrace celkových bílkovin, močoviny a celkového cholesterolu $(p<0.05)$. Byl zaznamenán pozitivní vliv zvyšování intenzity růstu na koncentraci celkového cholesterolu $(\mathrm{r}=0,52$; $p<0,05)$ a negativní závislost mezi růstovou intenzitou a aktivitou ALT ( $\mathrm{r}=-0,50$; $p<0,05)$, AST $(\mathrm{r}=-0,46 ; p<0,05)$, a hořčíku $(\mathrm{r}=-0,35 ; p<0,05)$. Věk sledovaných zviŕrat, ovlivnil koncentraci plazmatického trijodtyroninu $(\mathrm{r}=-0,45 ; p<0,05)$, ALP $(\mathrm{r}=-0,64 ; p<0,05)$, močoviny $(\mathrm{r}=-0,66 ; p<0,05)$ a železa $(\mathrm{r}=-0,34 ; p<0,05)$. Zjištěné hodnoty parametrů vnitřního prostředí se nacházely v rámci fyziologického rozmezí a tak napomohou zvýšit přesnost posuzování zdravotního a nutričního stavu zvířat chovaných v extenzivních podmínkách systému chovu bez tržní produkce mléka.

\section{Acknowledgement}

The present study was supported by the grant projects IGA MZLU 4 and 14/2007, research project MZE0002701403 and research project MSM6215648905.

\section{References}

Ban-Tokuda T, Orden EA, Bariio AN, Lapitan RM, Delevaud C, Chilliard Y, Fujihara T, Cruz LC, Homma H, Kanai F 2007: Effects of species and sex on plasma hormone and metabolite concentrations in crossbred Brahman cattle and crossbred water buffalo. Livest Sci 107: 244-252

Bonnet M, Leroux C, Faulconnier Y, Hocquette JF, Bocquier F, Martin P, Chilliard Y 2000: Lipoprotein lipase activity and mRNA are up-regulated by re-feeding in adipose tissue and cardiac muscle of sheep. J Nutr 130: 749-756

Bonnet M, Faulconnier Y, Hocquette JF, Bocquier F, Leroux C, Martin P, Chilliard Y 2004: Nutritional status induces divergent variations of GLUT4 protein content, but not lipoprotein lipase activity, between adipose tissues and muscles in adult cattle. Br J Nutr 92: 617-625

Bruss ML 1997: Lipids and ketones. In: Kaneko JJ, Harvey JW, Brus ML (Eds). Clinical biochemistry of domestic animals. $5^{\text {th }}$ ed. Academic Press, San Diego, CA, pp. 83-115

Cavestany D, Blanc JE, Kulcsar M, Uriarte G, Chilibroste P, Meikle A, Febel H, Ferraris A, Krall E 2005: Studies of the transition cow under a pasture-based milk production system: metabolic profiles. J Vet Med A-Physiol Pathol Clin Med 52: 1-7

Godden SM, Kelton DF, Lissemore KD, Walton JS, Leslie KE, Lumsden JH 2001: Milk urea testing as a tool to monitor reproductive performance in Ontario dairy herds. J Dairy Sci 84: 1397-1406

Grünwaldt EG, Guevara JC, Estévez OR, Vicente A, Rousselle H, Alcuten N, Aguerregaray D, Stasi CR 2005: Biochemical and haematological measurements in beef cattle in Mendoza plain rangelands (Argentina). Trop Anim Health Prod 37: 527-540

Kaneko JJ, Harvey JW, Bruss ML 1997: Clinical biochemistry of domestic animals. Academic Press, San Diego, CA, 741 p.

Knowles TG, Edwards JE, Bazeley KJ, Brown SN, Butterworth A, Warriss PD 2000: Changes in the blood biochemical and haematological profile of neonatal calves with age. Vet Rec 147: 593-598

Ndlovu T, Chimonyo M, Okoh AI, Muchenje V, Dzama K, Raats JG 2007: Assessing the nutritional status of beef cattle: Current practices and future prospects. Afr J Biotechnol 6: 2727-2734 
Otto F, Vilela F, Harun M, Taylor G, Baggasse P, Bogin E 2000: Biochemical blood profile of Angoni cattle in Mozambique. Isr J Vet Med 55: 150-159 http://www.isrvma.org/article/55_3_4.htm

Parra O, Ojeda A, Combellas J, Gabaldon L, Escobar A, Martinez N, Benezra M 1999: Blood metabolites and their relationship with production variables in dual-purpose cows in Venezuela. Prev Vet Med 38: 133-145

Pereira AMF, Baccari F Jr, Titto EAL, Almeina JAA 2008: Effect of thermal stress on physiological parameters, feed intake and plasma thyroid hormones concentration in Alentejana, Mertolenga, Frisian and Limousine cattle breeds. Int J Biometeorol 52: 199-208

Sasaki O, Yamamoto N, Togashi K, Minezawa M 2002: Plasma metabolites concentrations in calves until 90 days of age for estimating genetic ability for milk production traits. Asian Australas J Anim Sci 15: 1813-1821

Suttle N 1993: Overestimation of copper deficiency. Vet Rec 133: 123-124

Wittwer F, Bohmwald H, Contreras P, Phil M, Filoza J 1987: Analisis de los resultados de perfiles metabolicos obtenidos en rebaños lecheros en Chile. Arch Med Vet (Chile) 19: 35-45

Whitaker DA Goodger WJ, Garcia M, Perera BMAO, Wittwer F 1999: Use of metabolic profiles in dairy cattle in tropical and subtropical countries on smallholder dairy farms. Prev Vet Med 38: 119-131 
